\title{
Poverty Attributions and Emotions Associated with Willingness to Help and Government Aid
}

\author{
Lucas Yúdica ${ }^{1}$, Franco Bastias ${ }^{12}$, and Edgardo Etchezahar ${ }^{3}$ \\ ${ }^{1}$ Catholic University of Cuyo, San Juan, Argentina \\ ${ }^{2}$ National Scientific and Technical Research Council, Buenos Aires, Argentina \\ ${ }^{3}$ Interdisciplinary Center for Research in Mathematical and Experimental Psychology - \\ National Scientific and Technical Research Council (CIIPME-CONICET), \\ Buenos Aires, Argentina \\ ${ }^{3}$ University of Buenos Aires, Buenos Aires, Argentina \\ ${ }^{3}$ National University of Lomas de Zamora (UNLZ), Lomas de Zamora, Argentina
}

\begin{abstract}
This study aims to understand how willingness to help people in poverty and the agreement with providing government aid are connected to emotions and attributional processes, in a country with a high poverty rate such as Argentina. Differences in poverty attributions and emotions among selfreported social class are also analysed. A total sample of 331 secondary-school students completed self-administered questionnaires. Correlations and regression analyses showed that, whereas emotions such as compassion, empathy and pity seem to motivate helping behaviours, explanations as to the cause of poverty, rather than emotions, are closely associated with an agreement to providing government aid. However, low levels of anger seem to be required to endorse both helping behaviours and agreement to providing government aid. On the other hand, respondents who selfidentify as belonging to upper classes report more anger and use fewer structural explanations to understand poverty than lower-classes respondents. We propose that future research analyse a greater variety of helping behaviours towards people in poverty and types of government intervention in the global south.
\end{abstract}

Keywords: causal attributions, emotions, government aid, poverty, helping behaviour

Lucas Yúdica, Catholic University of Cuyo, Ángel Grígolo 59 (sur), Santa Lucía, 5411 San Juan, Argentina. E-mail: lyudica@uccuyo.edu.ar

Note:

The second author of this article is the beneficiary of a doctoral fellowship co-financed by the Catholic University of Cuyo (UCCuyo), the National Scientific and Technical Research Council (CONICET) and the Secretary of State for Science, Technology and Innovation of San Juan (SECITI).

Lucas Yúdica: https://orcid.org/0000-0002-4011-3152

Franco Bastias: https://orcid.org/0000-0002-9477-1417

Edgardo Etchezahar: https://orcid.org/0000-0002-3289-194X 


\section{Introduction}

The issue of poverty currently makes up a large part of the political agenda around the world and is the focus of attention and concern in many societies. Various actions, interventions and strategies have been implemented at different levels in order to reduce or attempt to eradicate poverty. We can distinguish two main types of interventions to tackle the problem. On the one hand, government's interventions through public policies are specifically designed to help their most vulnerable citizens. On the other hand, there are civil society's interventions through diverse social actions to directly or indirectly help people in poverty - for example, participating as volunteers for non-governmental organizations (NGOs), making donations or joining a demonstration. Social psychologists have wondered what variables are associated with taking action to reduce poverty. Such is the case with causal attributions and emotional reactions to poverty.

Attributional processes began to be studied during the 1970s, as they relate to poverty (Feagin, 1972; Feather, 1974). The concept of causal attributions for poverty refers to the judgments that individuals make to explain why people find themselves in poverty. For example, whether an individual blames or doesn't blame the poor person for his situation in relation to the importance given to dispositional factors (e.g. lack of willingness or aspiration) and situational factors (e.g. low salaries or corrupt governments). In almost 50 years of studies of poverty attributions, there is a broad proposal of types of attributions. Pioneering authors proposed the tripartite dimensionality: individualistic, structural, and fatalistic factors (e.g., Feagin, 1972; Feather, 1974); while others considered cultural factors (e.g., Cozzarelli et al., 2001; Reyna \& Reparaz, 2014) or offered greater complexity looking at the controllability, location and stability of the causal agent (e.g., Osborne \& Weiner, 2015; Zucker \& Weiner, 1993).

According to Weiner (2019), the study of attributions has been in force for so many years in part because of its relational fertility, that is, it embraces many interrelated constructs including cognitions, emotions, and behaviours. Regarding the relationship between attributions and emotions, findings show that negative emotions such as anger and aggression towards people in poverty are dominant when poverty is attributed to factors controlled by the person, which include laziness and lack of willingness (Osborne \& Weiner, 2015; Weiner, 2006). In contrast, positive emotions are dominant when poverty is attributed to external factors or factors out of the control of the individual, which include lack of educational or work opportunities and even physical disability (Feldman \& Crandall, 2007; Osborne \& Weiner, 2015; Reyna \& Reparaz, 2014). Moreover, certain emotions either promote or discourage different prosocial behaviours. Positive emotions have a direct relationship with the behaviours of helping (González \& Lay, 2017; Klebaniuk, 2018; Yúdica et al., 2020; Bastias \& Cañadas, 2021), civic commitment (LuengoKanacri et al., 2016), volunteering and making donations (Willer et al., 2015). 
Nevertheless, in addition to the actions that citizens themselves can take to reduce poverty, their agreement, support and demands of government action are fundamental for large-scale intervention. Different studies have shown that this agreement with support of public policies to reduce poverty is associated with causal attributions of poverty (Bullock, 1999; Kluegel \& Smith, 1986; Yúdica et al., 2020) and emotions that are a consequence of these attributional processes (HernandezRamos et al., 2019; Zucker \& Weiner, 1993). For example, those who attribute poverty to structural causes also tend to desire equity among classes (Piff et al., 2020), support government programs that benefit the poor (Delavega et al., 2017) and demonstrate mostly positive attitudes towards citizens who find themselves in poverty (Toikko \& Rantanen, 2017).

Despite there being a number of studies on this topic, only few of them deal with populations from continents or regions with high poverty rates. For example, in the case of causal attributions, the majority of research has been carried out in Europe and the United States, with very few from Africa (e.g., Baguma \& Furnham, 2012), Asia (e.g., Halik \& Webley, 2011) and Latin America (e.g., Bastias et al., 2019; Reyna \& Reparaz, 2014). This has been one of the most frequent criticisms of this line of study (Bastias et al., 2019; Dakduk et al., 2010; Harper, 2003). In our study, we work with a sample from a world region characterized by poverty and inequality. This is especially relevant since individuals' opinions and perceptions of the causes of poverty are influenced by their own country's culture and social issues (Pirani, 2013). For example, in a comparative study among 15 European countries, Da Costa and Dias (2013) show that most developed countries emphasize the individualistic and fatalistic causes of poverty, whereas the least developed countries explain poverty based on the injustices of society. For these authors, respondents' involvement with poverty and their personal experience with this situation may lead them to be more sympathetic to this social phenomenon and assign it to external factors, such as blaming society for poverty. This inference might also be extended within the same country to explain the differences among social classes in their explanations of poverty. Studies have shown that the representatives of higher classes and higher socioeconomic status (SES) are significantly more likely to endorse individualistic than structural explanations for poverty, while representatives of lower class and lower SES are more inclined to support structural rather than individualistic beliefs (Gonzalez \& Lay, 2017; Kluegel \& Smith, 1986). The results are similar when considering subjective SES or self-perceived social class (Bastias et al., 2019).

The objective of the present work is to study a sample from Argentine of how emotions and attributional processes are related to personally helping people facing poverty and to agreement with government intervention. Likewise, our research seeks to analyse if there are differences in attributions and emotions experienced towards people in poverty in accordance with the social class in which these adolescents position themselves. We decided to work with a sample of school-age 
adolescents, from a very diverse social background, because this study is framed in a broader research program that aims to design educational interventions to promote helping behaviour within the classroom.

\section{Hypothesis}

H1. Based on previous research (Feldman \& Crandall, 2007; Osborne \& Weiner, 2015; Reyna \& Reparaz, 2014; Weiner, 2006), individualistic attributions would show a negative correlation with experiencing empathy, compassion, and pity towards people in poverty and a positive correlation with experiencing anger. Structural attributions would present a positive correlation with empathy, compassion and pity and a negative correlation with anger.

H2. Based on previous research (Bullock, 1999; Delavega et al., 2017; Kluegel \& Smith, 1986; Yúdica et al., 2020; Zucker \& Weiner, 1993), individualistic causal attributions would show a negative correlation with the willingness to provide help and agreement with government aid, whereas the structural causal attributions would present a positive correlation with help and government aid.

H3. Based on previous research (Gonzalez \& Lay, 2017; Hernandez-Ramos et al., 2019; Klebaniuk, 2018; Yúdica et al., 2020; Zucker \& Weiner, 1993), willingness to provide help to those in poverty and agreement with government aid would show a positive correlation with emotional reactions of pity, empathy, and compassion towards people in poverty, as well as a negative correlation with anger.

H4. Based on previous research (Weiner, 1985; Zucker \& Weiner, 1993), emotions are better predictors of helping intentions, while attributions are better in predicting support of government aid.

H5. Based on previous research (Bastias et al., 2019), in comparison with upper-social-class respondents, lower-social-class respondents would show higher scores in structural attributions, emotions of empathy and compassion toward people in poverty and lower scores in individualistic attributions.

\section{Method}

\section{Participants}

We selected a convenience non-probability sample of 331 students from different secondary school institutions in the province of San Juan, Argentina. Of these students, $55.2 \%(n=174)$ attended a public institution and $44.8 \%(n=141)$ 
attended a private institution. Participants ranged in age from 14 to 20 years old $(M=17.58 ; S D=1,220)$ and of the total, $54.8 \%(n=181)$ were male and $45.2 \%$ $(n=149)$ were female. With respect to self-perceived social class, only $2.5 \%(n=8)$ reported being in the upper class, 39.9\% $(n=126)$ placed themselves in the uppermiddle class, $54.7 \%(n=173)$ were in the lower-middle class and $2.8 \%(n=9)$ came from the lower social class.

\section{Measures}

For the present study, we employed a self-administered questionnaire which was composed of the following measures:

\section{Sociodemographic Variables}

We included specific questions to determine sociodemographic variables, including age, sex, self-perceived social class (lower, lower-middle, upper-middle, upper) and type of secondary school institution (public or private).

\section{Scale of Causal Attributions for Poverty}

We applied a validated and adapted version for the context of Argentine done by Gatica et al. (2017), based on Bullock et al.'s (2003) scale. It is a self-administered questionnaire of 32 items with Likert-type responses, with the following introductory statement: "Think for a moment about why you believe that people are in poverty. We will present you with a list of possible causes of poverty. Please indicate the importance of each of these as possible causes of poverty, from 1 (not at all important) to 5 (very important)". Of the total items, 15 refer to structural causes (e.g., "a weak social safety net that does not allow people to recover financially"), 12 refer to individualistic attributions (e.g., "alcohol and drug abuse"), and 7 refer to fatalistic attributions (e.g., "because poverty is inevitable"). The items in each subscale are averaged to provide a total score, where greater point value indicates more attributions of this type. In the current work, we obtain a reliability of $\alpha=.81$ for the individualistic subscale, $\alpha=.80$ for structural subscale and .61 for fatalistic attributions.

\section{Emotional Reactions}

To evaluate these, we asked the following question: "How much (emotion) do you feel towards a person in poverty?" We formulated this question making sure to focus on the participant's emotions towards the person in poverty and not towards poverty itself. Likert-type responses of five points were provided $(5=m u c h$ and $1=$ nothing). Four emotions were evaluated: pity, empathy, compassion and anger; all 
considered in previous similar studies (Hart et al., 2008; Zucker \& Weiner, 1993) ${ }^{1}$. Among the mentioned emotions, pity and anger were translated into Spanish in two different ways: lástima and pena for pity, enojo and bronca for anger. Subsequent analysis showed that lástima and enojo, rather than pena and bronca, were emotions associated with greater intensity to other variables under study. Lastly, the order of presentation of these positive and negative emotions was random, to prevent possible bias in the responses.

\section{Willingness to Personally Provide Help}

Based on what proposed Zucker and Weiner (1993), the following item was included: "From 1 to 5, rate how likely would you be to personally help a person in poverty, if given an opportunity to do so". A Likert-type response format with five anchors was used, where 1 is in total disagreement and 5 is in total agreement.

\section{Agreement with Government Intervention}

Based on what proposed Zucker and Weiner (1993), the following item was included: "From 1 to 5, rate how strongly do you believe that people in poverty are deserving of government aid". A Likert-type response format with five anchors was used, where 1 is in total disagreement and 5 is in total agreement. This broad statement delves generally into the question of how deserving of government assistance or aid participants consider people in poverty to be.

\section{Procedure}

Data collection took place during an educational fair which helps students to determine their university path. This fair was held in June 2018 at the facilities of the university organizing the event. Self-administered questionnaires were used, which were answered by 369 adolescents. After cleaning the data, it was decided not to use 38 of the questionnaires because they were over 50\% incomplete. Participants needed between 10 and 15 minutes to respond to the questions included as part of the instrument. All participants were informed that the data gathered would be used for academic and scientific purposes and they signed giving their consent. According to the Ministry of Health in Argentina (Ministry of Health, 2020), in non-invasive or lower-health-risk research with adolescents, informed consent from parents is not required. In those cases, the exercise of the adolescent's autonomy is considered (Civil and Commercial Code of the Argentine Republic, 2015).

\footnotetext{
${ }^{1}$ Furthermore, we took into account a study carried out in Argentina regarding the words -including emotions- most frequently evoked before the inducing term "poor person" (Bastias \& Barreiro, in press).
} 


\section{Results}

We first evaluated the reliability of the scales utilized (see Method section) and then calculated arithmetic means and correlations. As can be observed in Table 1, willingness to personally help people in poverty showed a positive correlation with the emotions of compassion $(r=.33, p<.01)$, empathy $(r=.26, p<.01)$ and pity $(r=.21, p<.01)$. A positive relationship also exists, though with less intensity, between personal help and structural causal attributions $(r=.12, p<.05)$. Regarding government intervention, those who were in favour, mainly expressed empathy towards people in poverty $(r=.25, p<.01)$, although less intense correlation was observed with compassion $(r=.19, p<.01)$, pity $(r=.13 ; p<.05)$. In contrast, individuals who did not agree with government intervention also express emotions of anger towards people in poverty $(r=-.21, p<.01)$.

\section{Table 1}

Means, Standard Deviations and Correlations of the Variables Under Study

\begin{tabular}{lccccccccccc}
\hline & $M$ & $S D$ & 1 & 2 & 3 & 4 & 5 & 6 & 7 & 8 & 9 \\
\hline 1. Individualistic & 3.60 & 0.718 & - & & & & & & & \\
2. Structural & 3.48 & 0.614 & $.18^{* *}$ & - & & & & & & \\
3. Fatalistic & 2.05 & 0.863 & .05 & .06 & - & & & & & \\
4. Pity & 3.34 & 1.264 & .05 & $.30^{*}$ & .51 & - & & & & \\
5. Compassion & 3.70 & 1.164 & -.06 & $.49^{* *}$ & .06 & $.47^{* *}$ & - & & & \\
6. Empathy & 3.66 & 1.183 & .01 & $.22^{* *}$ & -.11 & $.22^{* *}$ & $.48^{* *}$ & - & & \\
7. Anger & 1.74 & 1.165 & .08 & -.09 & .08 & .00 & -.02 & -.02 & - & & \\
8. Help & 4.13 & 1.009 & -.03 & $.12^{*}$ & -.02 & $.21^{* *}$ & $.33^{* *}$ & $.26^{* *}$ & $-.17^{* *}$ & - & \\
9. Government aid & 3.41 & 1.215 & $-.20^{* *}$ & $.25^{* *}$ & .00 & $.13^{* *}$ & $.19^{* *}$ & $.25^{* *}$ & $-.21^{* *}$ & $.24^{* *}$ & - \\
\hline
\end{tabular}

${ }^{*} p<.05 ;{ }^{* *} p<.01$.

With respect to causal attributions, there is a negative correlation between individualistic attributions and agreement with government intervention to reduce poverty $(r=-.20, p<.01)$. On the other hand, those students who agreed with this intervention gave high point values to structural attributions $(r=.25, p<.01)$. Fatalistic attributions do not show any association with support for government intervention.

We compare the mean of the variables studied between social classes. Since few participants positioned themselves in the upper class $(n=8)$ and lower class $(n=9)$, the four original social class categories - upper, upper-middle, lower-middle and lower - were recorded and grouped in two values, the upper classes and the lower classes.

Among the findings, which are presented in Table 2 and Figure 1, the only type of attribution that show a statistically significant difference is the structural $\left(t_{(316)}=\right.$ $-2.73, p<.001$; Cohen's $d=0.30$ ), with the upper-classes respondents slightly exhibit 
more structuralist outlooks $(M=3.35, S D=0.61)$ than the lower-classes respondents $(M=3.53, S D=0.59)$. On the other hand, the emotion that showed a statistically significant difference between the groups was anger $\left(t_{(316)}=3.21, p<.01\right.$; Cohen's $d=0.38$ ). Students who perceive themselves in upper classes are significantly more likely to experience anger towards people living in poverty $(M=1.98, S D=1.31)$, in comparison with those who consider themselves in lower classes $(M=1.54, S D=$ $0.98)$.

Table 2

Differences in Mean According to Self-Perceived Social Class

\begin{tabular}{lccccccc}
\hline & \multicolumn{2}{c}{ Total } & \multicolumn{2}{c}{ Upper classes } & \multicolumn{3}{c}{$\begin{array}{c}\text { Lower classes } \\
(\boldsymbol{n}=\mathbf{1 8 2})\end{array}$} \\
\hline & $M$ & $S D$ & $M$ & $S D$ & $M$ & $S D$ & $t$-test \\
\hline Individualistic & 3.60 & 0.72 & 0.57 & 0.71 & 3.59 & 0.72 & -0.31 \\
Structural & 3.48 & 0.61 & 3.35 & 0.61 & 3.53 & 0.59 & $-2.73^{* *}$ \\
Fatalistic & 2.05 & 0.86 & 2.01 & 0.85 & 2.07 & 0.87 & -0.58 \\
Pity & 3.34 & 1.26 & 3.30 & 1.27 & 3.31 & 1.26 & -0.06 \\
Compassion & 3.70 & 1.16 & 3.55 & 1.22 & 3.80 & 1.13 & -1.76 \\
Empathy & 3.66 & 1.18 & 3.58 & 1.18 & 3.70 & 1.19 & -0.87 \\
Anger & 1.74 & 1.17 & 1.98 & 1.31 & 1.54 & 0.98 & $3.28^{* * *}$ \\
Help & 4.13 & 1.01 & 4.16 & 0.98 & 4.11 & 1.04 & 0.39 \\
Government aid & 3.41 & 1.21 & 3.45 & 1.27 & 3.39 & 1.16 & 0.46 \\
\hline
\end{tabular}

${ }^{*} p<.05 ;{ }^{* *} p<.01$.

\section{Figure 1}

Emotional Reactions According to Self-Perceived Social Class

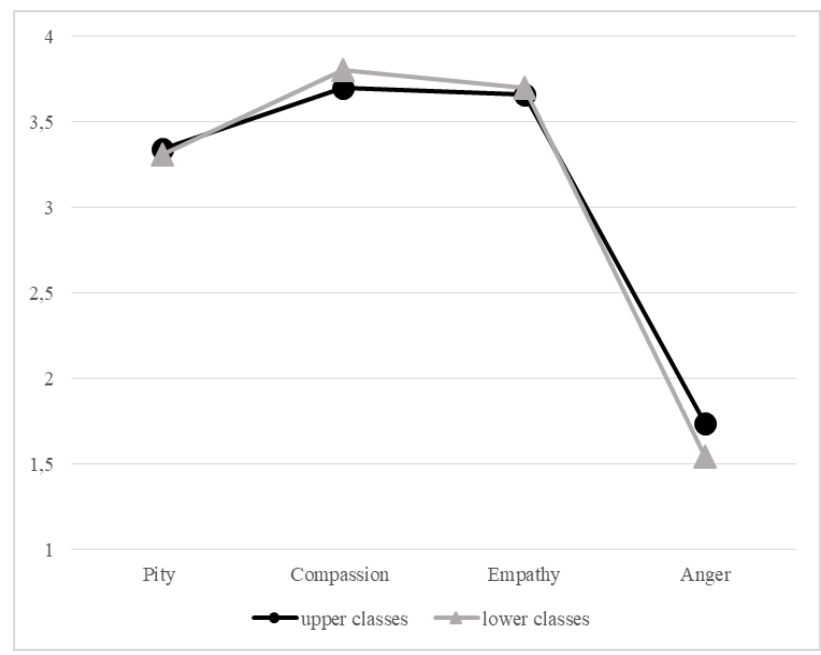


Finally, we performed a linear regression analysis to explore if there were differences in emotions and attributions as predictor variables of personal help and government aid. As can be seen in Table 3, the main predictors of an individual's willingness to personally help people in poverty are compassion and anger (reverse code), whereas none of the attributions were significant. Regarding government aid, the main predictors were structural attributions and individualistic attributions (reverse code), while, to a lesser extent, empathy and anger (reverse code) were also significant. The coefficient of determination for both personal help and government aid was low.

Table 3

Predictors of Help and Government Aid by Emotions and Attribution's

\begin{tabular}{lccccc}
\hline & \multicolumn{2}{c}{ Help } & & \multicolumn{2}{c}{ Government Aid } \\
\cline { 2 - 3 } \cline { 5 - 6 } Predictors & $\beta$ & $t$ & & $\beta$ & $t$ \\
\hline Pity & .06 & 1.06 & & .06 & 1.00 \\
Anger & $-.13^{* *}$ & -2.38 & & $-.15^{* *}$ & -2.75 \\
Compassion & $.25^{* * *}$ & 3.70 & & .04 & 0.67 \\
Empathy & .12 & 1.96 & & $.16^{* *}$ & 2.56 \\
Individualistic & -.01 & -0.22 & & $-.25^{* * *}$ & -4.60 \\
Structural & .04 & 0.78 & & $.21^{* * *}$ & 3.74 \\
Fatalistic & .01 & 0.13 & & .06 & 0.74 \\
\hline$\Delta R^{2}$ & .139 & & & .166 & \\
\hline
\end{tabular}

Note. Help: "From 1 to 5, rate how likely you would be to personally help a person in poverty, if given an opportunity to do so"; Government Aid: "From 1 to 5, rate how strongly do you believe that people in poverty are deserving of government aid". ${ }^{* *} p<.01 ;{ }^{* * *} p<.001$.

\section{Discussion}

This work analyses emotional reactions and causal attributions linked to a willingness to help people facing poverty and to agreement with government intervention. Furthermore, it also aims to compare attributions and emotions experienced toward people in poverty by participants according to their selfperceived social class. Our proposal is to clarify the relationships between these variables, which have generally been studied in prosperous nations, in a context characterized by poverty and inequality.

Descriptive analysis indicates that participants give more importance to individualistic causal attributions than to structural attributions. However, the differences between these two types of causes are not statistically significant; thus, we might speak of mixed explanations between structural-individualistic factors.

The lack of importance given to fatalistic factors was somewhat expected. The little relevance given to luck, fate or God as determining factors of poverty has also 
been observed in other studies (Bullock, 1999; Delavega et al., 2017; Kluegel \& Smith, 1986; Piff et al., 2020; Toikko \& Rantanen, 2017), even in those using an Argentine sample with the same scale for measuring attributions (Bastias et al., 2019; Gatica et al., 2017). This suggests that considering poverty as a result of factors that do not depend on people in poverty or the socioeconomic structure is not common. In other words, the causes of poverty tend to be considered as controllable by humans.

We might ask ourselves if the relative weight of factors that cause poverty could vary in the current context of the COVID-19 pandemic, the moment in which this text has been written. A pandemic could be classified as a fatalistic factor, as it is external to the people in poverty, and the government can mitigate only some aspects of its effects on health and the economy. We propose that future studies delve into how people explain poverty, which has now been exacerbated by the global health and economic crisis.

Upon analysing the relationships between attributions and emotions, no correlation was found between the individualistic causes and the four emotions evaluated. Although this relationship, expected in hypothesis 1, was not found, structural causes were linked to emotions. The attributions seem to be linked to an emotional response when poverty is thought to be the result of external factors present in the social structure. Respondents who endorse structural explanations of poverty feel more pity, compassion, empathy, and less anger towards people in poverty. This result coincides with previous studies, where participants generally express positive emotions when their attributive processes are structural in type (Cozzarelli et al., 2001; Feldman \& Crandall, 2007; Reyna \& Reparaz, 2014).

The findings allow confirmation of Hypothesis 2, since participants who tend to explain poverty using structural factors manifest greater support for government intervention. This agrees with results from studies carried out in different countries (Bullock et al., 2003; Delavega et al., 2017; Feagin, 1972; Piff et al., 2020; Toikko \& Rantanen, 2017). For these people, poverty would be caused, for example, by low salaries, high taxes and a capitalist system, among others; thus, they tend to believe that the government should intervene. On the other hand, those who adopt individual outlooks - considering, e.g., laziness or lack of motivation as a cause of poverty disagree with government interference probably because those interventions have no basis since the problem is an individual one and its solution should come from the poor themselves. From this viewpoint, to break out of poverty, people must change their own attitudes and actions and not expect aid policies. Furthermore, instead of contributing to the solution, government aid perhaps fosters the poverty it sets out to reduce by encouraging laziness and/or dependency, for example. Thus, we consider that poverty seen from a structural perspective might be the foundation for supporting policies of social welfare.

In addition, the agreement with government aid is also related to emotions. People who show greater support for government aid also express empathy, 
compassion, and pity, while those who disagree express anger towards people in poverty. Moreover, personal help is even closer related to emotions (pity, compassion, and empathy), showing a positive correlation with them. Those results confirm the hypothesis 3 and highlight the importance that other authors have given to emotions by promoting helping behaviours (González \& Lay, 2017; HernandezRamos et al., 2019; Klebaniuk, 2018; Luengo-Kanacri et al., 2016; Solak, 2015; Willer et al., 2015).

Even though both emotions and attributions are associated with personal help and government aid, there is an important difference in the degree of these correlations. As expected in hypothesis 4, where causal attributions are associated primarily with an agreement with government intervention, emotions do the same with personal help. Regression analyses showed that emotions of compassion and anger (reverse code) are predictors of personal help, but none of the attributions was significant. For government aid both emotions and attributions were predictors; however, the main predictors here were structural attributions and individualistic (reverse code) and, to a lesser extent, empathy, and anger (reverse code). To illustrate this point, we mention some features which differentiate the action of personally helping from demanding government intervention: the latter is remote or indirect help, with clear distance in interpersonal contact. In this sense, following Weiner (1985; Zucker \& Weiner, 1993), the more the intervention or aid involves interpersonal relationships, the greater the influence of emotions, while the influence of cognition, such as the attribution processes, decreases. The findings of this study highlight the importance of differentiating between the different types of helping behaviour and interventions to reduce poverty according to degrees of interpersonal contact. Future studies could explore motivations for helping behaviour considering a wide array of actions taken when faced with poverty (direct or indirect, personal, or impersonal, group or individual).

According to hypothesis 5, some differences were expected in attributions and emotions according to self-perceived social class. In comparison with upper-socialclass respondents, lower-social-class respondents would show higher scores in structural attributions, lower scores in individualistic attributions and higher empathy and compassion toward people in poverty. Nevertheless, significant differences were found only for structural attributions and anger. That is, compared to lower-class respondents, upper-class respondents place less importance on structural factors as determinants of poverty and feel more anger towards people in poverty. Given that the studies that explore attributions and emotional differences focus mainly on the objective indicator of SES (Bullock, 1999; Furnham, 1982; Gonzalez \& Lay, 2017; Kluegel \& Smith, 1986), the present study represents one of the few attempts to recognize these differences between groups by a subjective social class (with some exceptions, Bastias et al., 2019; and Nasser, 2007).

Some limitations of this work are mentioned. First, Cronbach's alpha coefficient for fatalistic subscale was less than satisfactory. According to Castillo and Rivera- 
Gutiérrez (2018) and with some evidence of low reliability in this dimension (Bastias et al., 2019; Gatica et al., 2017), we express concerns about the univocal existence of this factor, partially questioning the Feagin model (Feagin, 1972; Feather, 1974). Second, although significance was registered in the regressions, it is necessary to continue studying other possible variables that may increase the coefficient of determination. Third, a further limitation is that this work does not consider objective indicators of socioeconomic status, such as income, because based on previous experience, the respondents (secondary school students) are likely to be unaware of their household total income.

Lastly, we reiterate the importance from a social psychology standpoint of promoting studies on poverty in populations with high poverty rates. In line with this, we warn about the limitations of extrapolating conclusions from studies of the global north, where societies have very different experiences with poverty.

\section{References}

Baguma, P., \& Furnham, A. (2012). Attributions for and the perceived effects of poverty in east Africa: A study from Uganda. In S. C. Carr, M. MacLachlan, \& A. Furnham (Eds.), Humanitarian work psychology (pp. 332-350). Palgrave Macmillan.

Bastias, F., \& Barreiro, A. (in press). Who is poor? Analysis of social representations in an Argentine sample. Psico USF.

Bastias, F., Cañadas, B., Figueroa, M. C., Sosa, V., \& Moya, M. J. (2019). Explanations about poverty origin according to professional training area. Propósitos y Representaciones, 7(2), 107-120. http://dx.doi.org/10.20511/pyr2019.v7n2.282

Bullock, H. E. (1999). Attributions for poverty: A comparison of middle-class and welfare recipient attitudes. Journal of Applied Social Psychology, 29(10), 2059-2082. https://doi.org/10.1111/j.1559-1816.1999.tb02295.x

Bullock, H. E., Williams, W. R., \& Limbert, W. M. (2003). Predicting support for welfare policies: The impact of attributions and beliefs about inequality. Journal of Poverty, 7(3), 35-56. https://doi.org/10.1300/J134v07n03_03

Castillo, J. C., \& Rivera-Gutiérrez, M. (2018). Dimensiones comunes a las atribuciones de pobreza y riqueza [Common dimensions to the attributions of poverty and wealth]. Psykhe, 27(2), 1-10. http://dx.doi.org/10.7764/psykhe.27.2.1152

Código Civil y Comercial de la República Argentina. (2015). Libro primero, parte general (arts.19-140). Título I: Persona humana; Sección 2a: Persona menor de edad. [Civil and Commercial Code of the Argentine Republic. (2015). First book, general part (articles 19140). Title I: Human person; Section 2: Minor person]. http://servicios.infoleg.gob.ar/infolegInternet/anexos/235000-39999/235975/texact.htm\#6

Da Costa, L. P., \& Dias, J. G. (2014). Perceptions of poverty attributions in Europe: A multilevel mixture model approach. Quality \& Quantity, 48(3), 1409-1419. https://doi.org/10.1007/s11135-013-9843-3 
Cozzarelli, C., Wilkinson, A. V., \& Tagler, M. J. (2001). Attitudes toward the poor and attributions for poverty. Journal of Social Issues, 57(2), 207-227. https://doi.org/10. $1111 / 0022-4537.00209$

Dakduk, S., González, M., \& Malavé, J. (2010). Percepciones acerca de los pobres y la pobreza: Una revisión [Perceptions of the Poor and Poverty: A Review]. Revista Latinoamericana de Psicología, 42(3), 413-425. https://dialnet.unirioja.es/descarga/ articulo/3344771.pdf

Delavega, E., Kindle, P. A., Peterson, S., \& Schwartz, C. (2017). The blame index: Exploring the change in social work students' perceptions of poverty. Journal of Social Work Education, 53(4), 664-675. https://doi.org/10.1080/10437797.2017.1287028

Feagin, J. R. (1972). Poverty: We still believe that God helps those who help themselves. Psychology Today, 6(6), 101-110. http://hdl.handle.net/10822/764308

Feather, N. T. (1974). Explanations of poverty in Australian and American samples: The person, society, or fate? Australian Journal of Psychology, 26(3), 199-216. https://doi.org/10.1080/00049537408255231

Feldman, D. B., \& Crandall, C. S. (2007). Dimensions of mental illness stigma: What about mental illness causes social rejection? Journal of Social and Clinical psychology, 26(2), 137-154. https://doi.org/10.1521/jscp.2007.26.2.137

Furnham, A. (1982). Why are the poor always with us? Explanations for poverty in Britain. British Journal of Social Psychology, 21(4), 311-322. https://doi.org/10.1111/j.20448309.1982.tb00553.x

Gatica, L., Martini, J. P., Dreizik, M., \& Imhoff, D. (2017). Predictores psicosociales y psicopolíticos de la justificación de la desigualdad social [Psychosocial and psychopolitical predictors of the justification of social inequality]. Revista de Psicología, 35(1), 279-300. http://doi.org/10.18800/psico.201701.010

González, R., \& Lay, S. (2017). Sense of responsibility and empathy: Bridging the gap between attributions and helping behaviours. In E. van Leeuwen \& H. Zagefka (Eds.), Intergroup helping (pp. 331-347). Springer. https://doi.org/10.1007/978-3-319-53026-0_16

Halik, M., \& Webley, P. (2011). Adolescents' understanding of poverty and the poor in rural Malaysia. Journal of Economic Psychology, 32(2), 231-239. https://doi.org/10.1016/ j.joep.2009.02.006

Harper, D. (2003). Poverty and discourse. In S. Carr \& T. Sloan (Eds.). Poverty and psychology: From global perspective to local practice (pp. 185-203). Kluver Academia/Plenum.

Harth, N. S., Kessler, T., \& Leach, C. W. (2008). Advantaged group's emotional reactions to intergroup inequality: The dynamics of pride, guilt, and sympathy. Personality and Social Psychology Bulletin, 34(1), 115-129. https://doi.org/10.1177/ 0146167207309193 
Hernández-Ramos, P., Bachen, C. M., Raphael, C., Ifcher, J., \& Broghammer, M. (2019). Experiencing poverty in an online simulation: Effects on players' beliefs, attitudes and behaviors about poverty. Cyberpsychology: Journal of Psychosocial Research on Cyberspace, 13(3), article 1. http://dx.doi.org/10.5817/CP2019-3-1

Hernández-Sampieri, R., Fernández-Collado, C., \& Baptista-Lucio, P. (2014). Metodología de la Investigación [Investigation methodology]. McGraw Hill.

Klebaniuk, J. (2018). Emocje moralne jako wyznacznik pomagania członkom grup o niższym statusie [Moral emotions as a determinant of helping members of lower status groups]. Forum Oświatowe, 30(1), 119-135. https://forumoswiatowe.pl/index.php/czasopismo/ article/view/591

Kluegel, J. R., \& Smith, E. R. (1986). Beliefs about inequality: Americans' views of what is and what ought to be. Aldine de Gruyter.

Luengo-Kanacri, B. P., González, R., Valdenegro, D., Jiménez-Moya, G., Saavedra, P., Mora, E. A., \& Pastorelli, C. (2016). Civic engagement and giving behaviors: The role of empathy and beliefs about poverty. The Journal of Social Psychology, 156(3), 256-271. https://doi.org/10.1080/00224545.2016.1148006

Ministerio de Salud de Argentina. (2020). Pautas generales para la obtención del consentimiento informado para participar de una investigación [General guidelines for obtaining informed consent to participate in research.]. https://www.argentina.gob.ar/ salud/investiga

Nasser, R. (2007). Does subjective class predict the causal attribution for poverty? Journal of Social Sciences, 3(4), 197-201. https://doi.org/10.3844/jssp.2007.197.201

Osborne, D., \& Weiner, B. (2015). A latent profile analysis of attributions for poverty: Identifying response patterns underlying people's willingness to help the poor. Personality and Individual Differences, 85, 149-154. https://doi.org/10.1016/j.paid. 2015.05.007

Piff, P. K., Wiwad, D., Robinson, A. R., Aknin, L. B., Mercier, B., \& Shariff, A. (2020). Shifting attributions for poverty motivates opposition to inequality and enhances egalitarianism. Nature Human Behaviour, 4, 496-505. https://doi.org/10.1038/s41562020-0835-8

Pirani, E. (2013). Evaluating contemporary social exclusion in Europe: A hierarchical latent class approach. Quality \& Quantity, 47(2), 923-941. https://doi.org/10.1007/s11135011-9574-2

Reyna, C., \& Reparaz, M. (2014). Propiedades psicométricas de las Escalas de Atribuciones sobre las Causas de la Pobreza y Actitudes hacia los Pobres [Psychometric properties of the Attribution Scales on the causes of poverty and attitudes towards the poor]. Actualidades en psicología, 28(116), 55-66. http://dx.doi.org//10.15517/ap. v28i116.14892

Solak, N. (2015). The role of emotions and emotion regulation in the system justification process. [Unpublished doctoral thesis]. Middle East Technical University, Ankara, Turkey. http://etd.lib.metu.edu.tr/upload/12618678/index.pdf 
Toikko, T., \& Rantanen, T. (2017). How does the welfare state model influence social political attitudes? An analysis of citizens' concrete and abstract attitudes toward poverty. Journal of International and Comparative Social Policy, 33(3), 201-224. https://doi.org/10.1080/21699763.2017.1302892

Weiner, B. (1985). An attributional theory of achievement motivation and emotion. Psychological Review, 92(4), 548-573. https://doi.org/10.1037/0033-295X.92.4.548

Weiner, B. (2006). Social motivation, justice, and the moral emotions: An attributional approach. Psychology Press.

Weiner, B. (2019). Wither attribution theory? Journal of Organizational Behavior, 40(5), 603-604. https://doi.org/10.1002/job.2398

Willer, R., Wimer, C., \& Owens, L. A. (2015). What drives the gender gap in charitable giving? Lower empathy leads men to give less to poverty relief. Social Science Research, 52, 83-98. https://doi.org/10.1016/j.ssresearch.2014.12.014

Yúdica, L., Bastias, F., \& Cañadas, B. (2020). Explicaciones y emociones asociadas a la disposición a brindar ayuda a las personas pobres [Explanations and emotions associated with the willingness to help poor people]. Revista Argentina de Ciencias del Comportamiento (RACC), 12(1), 130-131. https://revistas.unc.edu.ar/index.php/racc/ issue/view/2105/326

Zucker, G. S., \& Weiner, B. (1993). Conservatism and perceptions of poverty: An attributional analysis. Journal of Applied Social Psychology, 23(12), 925-943. https://doi.org/10.1111/j.1559-1816.1993.tb01014.x 


\title{
Atribucije siromaštva i emocije povezane sa spremnošću za pomaganje i stavom prema pružanju državne pomoći
}

\begin{abstract}
Sažetak
Cilj je provedenoga istraživanja razumjeti kako su spremnost za pomaganje i suglasnost s pružanjem državne pomoći siromašnima povezani s emocijama i atribucijskim procesima u zemlji s visokom stopom siromaštva poput Argentine. Analizirane su također razlike u emocijama i atribuciji siromaštva među različitim društvenim klasama. U istraživanju je sudjelovao ukupno 331 srednjoškolac, a svi su sudionici ispunili set upitnika. Na temelju korelacijskih i regresijskih analiza može se zaključiti da, iako emocije poput suosjećanja, empatije i sažaljenja motiviraju ponašanja povezana s pomaganjem, atribucije uzroka siromaštva, a ne same emocije, usko su povezane sa suglasnošću s pružanjem državne pomoći siromašnima. Prema dobivenim je rezultatima niska razina ljutnje povezana i s ponašanjima povezanima s pomaganjem i sa suglasnošću s pružanjem državne pomoći siromašnima. Ispitanici koji se identificiraju kao pripadnici više klase izvještavaju o većoj ljutnji te koriste manje strukturirana objašnjenja za razumijevanje uzroka siromaštva $u$ odnosu na ispitanike koji pripadaju nižoj klasi. Predlažemo da se u budućim istraživanjima analizira više različitih ponašanja povezanih s pomaganjem siromašnima, kao i vrste vladinih intervencija u južnim područjima svijeta.
\end{abstract}

Ključne riječi: atribucije uzroka, emocije, državna pomoć, siromaštvo, ponašanje povezano s pomaganjem

Primljeno: 7. 12. 2020. 